\title{
Vernon B. Mountcastle
} 1918-2015

\section{Solomon H Snyder}

Vernon Mountcastle, widely regarded as the father of modern neuroscience, died peacefully in his Baltimore home Sunday, 11 January 2015. His discoveries fundamentally altered our understanding of how the cerebral cortex processes information, but especially sensory perception. Techniques he perfected fundamentally altered how systems neurophysiologists work out the ways in which neurons interact.

Vernon Benjamin Mountcastle, born in Shelbyville, Kentucky, on 15 July 1918, grew up in Roanoke, Virginia. A precocious student, he graduated high school at 16, then enrolled in Roanoke College and graduated in 3 years. He entered Johns Hopkins Medical School in 1938, where he remained for his entire career. Following graduation in 1942, Mountcastle joined the Navy as a physician. He participated in the Anzio invasion and escaped death when his ship's bottom was torn out, marooning Mountcastle on a rock-laden shore. He later participated in the Normandy invasion, where he again experienced harrowing close calls.

After the war, Mountcastle returned to Johns Hopkins hoping to pursue a residency in neurosurgery, but there were no openings. He agreed to spend a year working with the neurophysiologist Phillip Bard, famous for discovering brain structures underlying rage responses. While working on the classical rage reaction, he taught himself techniques for electrical recording and became so enamored of basic laboratory research that he never returned to clinical medicine.

One of Mountcastle's most notable breakthroughs was his elucidation in 1957 of the columnar organization of the cerebral cortex. Prior to that time, it was generally thought that the different layers of the cortex operated somewhat independently of each other. By contrast, Mountcastle concluded,

Evidence for columnar organization is simple and convincing ... in a microelectrode penetration made vertically to the cortical surface, one encounters at each succession of depth neurons with similar functional properties... In contrast, when preparations are made slanting across the vertical dimension of the cortex, one encounters successive blocks of tissue containing neurons with different properties ${ }^{1}$.

So radical was this concept that Mountcastle's experimental collaborators refused to be included as coauthors. In Mountcastle's own words,

Many friends have inquired why the description of this general principle is contained in a paper authored by me alone. The answer is... my two colleagues were so apprehensive over my proposal of such a radical hypothesis that they sought to disavow themselves from it.

Mountcastle was proved correct. The columnar organization was confirmed again and again by numerous investigators; most notably, by David Hubel and Torsten Wiesel in the visual cortex, for which they received a Nobel Prize in 1981.

Among numerous other advances, Mountcastle is particularly noted for his insights into the functions of the posterior parietal cerebral

Solomon H. Snyder is at the Solomon H. Snyder Department of Neuroscience, John Hopkins University School of Medicine, Baltimore, Maryland, USA.

e-mail: ssnyder@jhmi.edu

Published online 16 February 2015; doi:10.1038/nn.3958 cortex. Frustrated by unproductive results in the post-central cerebral cortex, he began recording in more posterior areas, notably the posterior parietal cortex, and, in his own words,

What we saw that day determined my experimental life for 15 years. Neural responses to stimuli occurred only if the animal attended to them-that is, if they seemed of interest to $\mathrm{him}^{1}$.

Mountcastle realized that this system could account for the sensory neglect of people with parietal lobe lesions.

Besides uncovering novel mechanisms of cortical function, Mountcastle pioneered research methodology. Earlier neurophysiologic work had employed anesthetized cats and monkeys, preparations that did not permit insights into brain function of awake, behaving primates. Recording from single neurons with microelectrodes while a monkey was carrying out complex behaviors was a seemingly insuperable challenge, which had eluded most neurophysiologists. Mountcastle was one of a tiny handful of investigators who began to characterize the firing of single neurons while monkeys were carrying out complex behavioral tasks.

Mountcastle's contributions have been recognized by numerous honors including the Albert and Mary Lasker Award (1983) and the National Medal of Science (1986). He was the recipient of eight honorary doctorates. He was an important citizen of Johns Hopkins and of the international neuroscience community. He helped set up an independent Department of Neurology at Johns Hopkins in the late 1960s and he was instrumental in launching the school's Department of Neuroscience in 1980. He was one of the founders of the Society for Neuroscience (SFN) and served as its first elected president. He enunciated the principle that SFN should be unlike other 'elite' groups with onerous membership requirements. Instead, SFN was open to all interested researchers. His efforts facilitated SFN's rapid growth from a few hundred members in 1970 to about 40,000 in 2014.

A workaholic, Mountcastle arrived by 7:00 a.m. at the lab each morning, went home for dinner at 6:00 p.m. and often returned for further work till midnight. It wasn't until we launched the Department of Neuroscience in 1980 that he decided to 'relax'. A college tennis star, he resurrected his talents in his later years, and he and I became weekly tennis partners. Bonding during shower and dressing, we shared ideas about the history of Johns Hopkins and its future prospects: myself the optimist about impending changes, whereas Mountcastle was strongly attached to 'the old days'. A Southern gentleman, he invariably dressed in elegant, light tan suits. He was an active participant in selected social clubs, notably the Caduceus Club, composed of eminent Baltimore physicians who gathered monthly for good food and conversation. A week after Mountcastle's death, their dinner meeting was devoted to reminiscences of his many years of close fellowship. He also began to spend much more time with his grandchildren. He maintained intellectual pursuits, writing highly influential review articles and several major books into his 90s.

A devoted family man, Mountcastle is survived by his wife Nancy, his son Vernon III, his daughter Ann Bainbridge, six grandchildren and two great-grandchildren. His son George died in an accident in 1969.

The world of the brain will sorely miss Vernon B. Mountcastle.

1. Mountcastle, V.B. Autobiography. in History of Neuroscience in Autobiography (ed. Squire, L.R.) Vol. 6, 344-380 (Society for Neuroscience, 2009). 